\title{
Population biology and sexual dimorphism in the freshwater prawn Atya scabra (Decapoda: Atyidae) in the Contas River, Bahia, Brazil
}

\author{
Matheus Souza Ferreira de Barros ${ }^{1 *}$, Tereza Cristina dos Santos Calado ${ }^{1}$, \\ Ewerton Vieira dos Santos ${ }^{1}$, Alberis Santos Silva ${ }^{1} \&$ Letícia Gomes de Andrade Albuquerque $^{1}$ \\ 1. Laboratórios Integrados de Ciências do Mar e Naturais, Universidade Federal de Alagoas, Maceió, Alagoas, Brazil; \\ matheus.barrosteu@gmail.com, terezacalado@gmail.com, ewertonvs@gmail.com, alberissantos001@gmail.com, \\ letgaa1997@gmail.com \\ * Correspondence
}

Received 09-VIII-2019. Corrected 04-III-2020. Accepted 12-V-2020.

\begin{abstract}
Introduction: Crustaceans have economic and ecological importance and the role of caridean crustaceans in lentic environments is crucial to maintain the trophic structure. The species Atya scabra is occasionally associated with fisheries, especially in Northeast and Northern Brazil. Objective: To determine the population structure, reproductive period, patterns of growth and distribution of size classes among sexes in a population of the prawn A. scabra in the De Contas River, Bahia, Brazil. Methods: Individuals were sampled in a period of one year by passing sieves through marginal vegetation and using dragnets. In the laboratory, we recorded the sex of the individuals and measured them using a pachymeter with $0.001 \mathrm{~mm}$ precision. The dimensions measured were CL (carapace length), TL (total length) and CW (carapace width). In order to analyze data, linear models for the relationships $\mathrm{CL} \times \mathrm{CW}$ were constructed and the type of allometry for each sex was determined. Individuals were grouped into size classes of $5 \mathrm{~mm}$ intervals. A chi-square test $\left(\chi^{2}\right)$ was used to test deviation from the 1:1 sex ratio. The proportion of ovigerous females was registered for each month to determine the breeding period. Results: A total of 517 individuals were collected, 328 were males and 186 females of which 169 were ovigerous. Males showed a polymodal distribution in size classes and were significantly larger than females, which presented a unimodal distribution in size classes. The observed growth patterns demonstrated that both sexes present negative allometry. However, sexual dimorphism was detected when comparing the growth parameters. Ovigerous females were sampled the entire year and size-frequency data demonstrated that recruitment also occurs throughout the year, which allowed us to classify their reproduction as continuous. Conclusions: Our data is essential to draw sustainable fishery management strategies. We suggest a minimum capture size of $70 \mathrm{~mm}$ and capture restrictions from May to August.
\end{abstract}

Key words: ecology; freshwater; limnology; conservation; morphometry.

Souza Ferreira de Barros, M., dos Santos Calado, T.C., Vieira dos Santos, E., Santos Silva, A., \& Gomes de Andrade Albuquerque, L. (2020). Population biology and sexual dimorphism in the freshwater prawn Atya scabra (Decapoda: Atyidae) in the De Contas River, Bahia, Brazil. Revista de Biología Tropical, 68(3), 743-751.

Crustaceans are economically important, being the aim of many fisheries, and also ecologically important, occupying the role of transferring nutrients to the higher trophic levels (Verdi, 1995). Caridean crustaceans, including the families Atyidae and Palaemonidae, are crucial components of limnological ecosystems located in tropical and subtropical regions (De Grave \& Fransen, 2011).

The family Atyidae, represented near exclusively by freshwater prawns, is characterized by the presence of unique feeding 
chelipeds, which count on complex structures on the first and second pair of pereiopods. These structures are used for capturing suspended matter (de Grave, Cai, \& Anker, 2008). This family is represented by four species in Brazil, two of the Potimirim (Holthuis, 1954) genus and two of the Atya Leach, 1815 genera (Melo, 2003). This family is commonly associated with rocky substrates and under vegetation for covering (Hobbs \& Hart, 1982).

The genus Atya is known for its specific habitat requirements, which consists of shallow oxygen-rich water (Hobbs \& Hart, 1982). The species Atya scabra (Leach, 1815), along with many species of the family Palaemonidae, is frequently associated with fisheries in many regions in Brazil, like Southern Bahia, North of Brazil (Almeida, Coelho, Luz, Santos, \& Ferraz, 2008; Almeida, Mossolin, \& Luz, 2010) and around the neotropical region (MartínezMayén, Román-Contreras, Rocha-Ramírez, \& Chazaro-Olvera, 2000; Lorán-Núñez, ValdézGuzmán, \& Martínez-Isunza, 2009), having its occurrence also reported in Puerto Rico, Panama and the dutch island of Curaçao, located in the Caribbean (Covich, 1988; Torati, Page, De Grave, \& Anker, 2011; Debrot, 2003). It has documented preference for high speed streams, which is linked with their capacity to resist the currents and foraging strategy (de Grave et al., 2008; Girard et al., 2013). This species is considered vulnerable in 10 Brazilian states, including the state of Bahia (Amaral, 2005).

Knowledge of allometric growth patterns is essential to determine sexual dimorphism in shrimps by comparison of growth parameters (Hartnoll, 1974). Also, it is an important tool when analyzing intraspecific variation among different populations (Costa \& Soares-Gomes, 2008). Data on relative growth can also be used as a diagnostic device to identify evolutionary relationships between species (Rahman \& Ohtomi, 2018).

Studies that deal with population structures and reproductive biology are important in the sphere of fishery management and conservation, being crucial to determine conservation status in the studied environment and tracing management strategies (Almeida et al., 2010). Thus, this study aimed to determine the population structure of the prawn Atya scabra in the Contas River, Bahia, Brazil, as well as its reproductive period, patterns of allometric growth, sexual dimorphism and size classes distribution among the sexes, helping to establish a minimum capture size in fisheries along the region.

\section{MATERIALS AND METHODS}

Study site: The Contas River is located in southern Bahia, Brazil (Fig. 1). The water depth rarely exceeds $1 \mathrm{~m}$ and the sediment is composed mostly of rocks, but with a few points of sand. The marginal vegetation presents a variable composition of macrophytes.

Field work: Shrimps were sampled between January and December 2009, by using drag nets for 20 minutes and passing sieves along the marginal vegetation, after removing rocks from the substrate, during $1 \mathrm{~h}$ in each sampling site. This type of sampling method has been utilized in other studies (Almeida et al., 2010; Galvão \& Bueno, 2000). We used a mercury thermometer to measure temperature twice in each sampling point and then means were calculated. The organisms were collected in containers with $70 \%$ alcohol and tagged.

Laboratory: In the laboratory, we determined the sex of the individuals by checking the presence (for males) or absence (for females) of an appendix in the second pair of pleopods. Individuals were also measured using a pachymeter with $0.001 \mathrm{~mm}$ precision. The following dimensions were measured: carapace width $(\mathrm{CW})$, as the distance between the medium points at the side of the carapace $(\mathrm{mm})$; carapace length $(\mathrm{CL})$, as the distance between the post-orbital margin to the posterior margin of the carapace $(\mathrm{mm})$; and total length (TL), as the distance from the post-orbital margin to the beginning of the telson. TL was preferred for most analyses. 


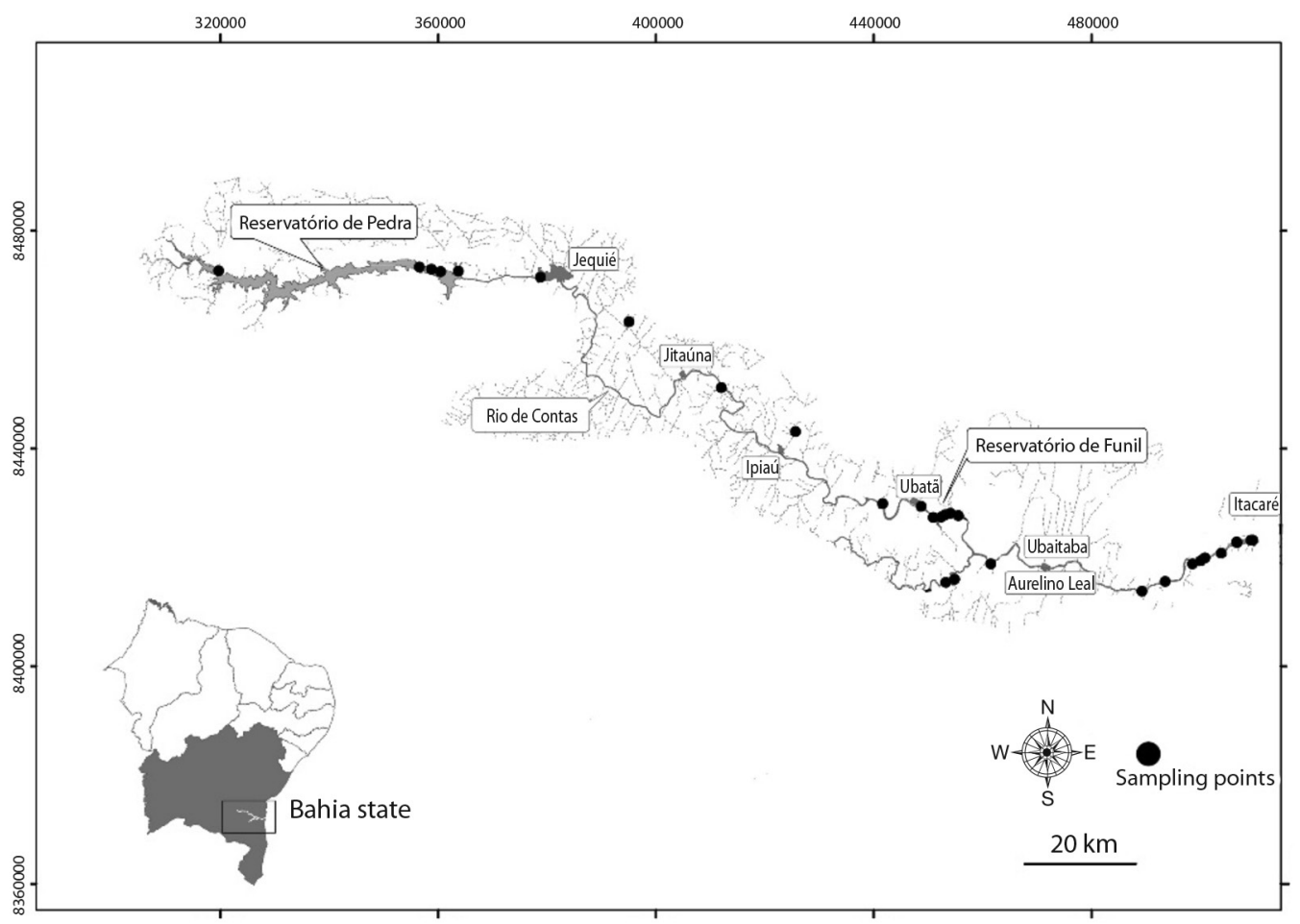

Fig. 1. Location of the sampling points in the Contas River, Southern Bahia, Brazil.

Data analysis: Linear models $(y=a x+b)$ for the $\mathrm{CL} \times \mathrm{CW}$ relationships were constructed. When $b>1$, positive allometry is registered. When $\mathrm{b}<1$, negative allometry is recorded and when $\mathrm{b}=1$, the relationship is isometric. CW (carapace width) was considered the independent variable and CL (carapace length) was considered the dependent variable. Individuals of both sexes were grouped into size classes of $5 \mathrm{~mm}$ for TL. A chi-square test $\left(\chi^{2}\right)$ was used to check if there was a significant deviation from the 1:1 normal sex ratio, which was considered as the number of males divided by the number of females. The presence of ovigerous females was computed for each month, considering as breeding period the months in which it was detected. Mean carapace length (CL) of males and females was compared by means of the Mann-Whitney $U$ test. An analysis of covariance (ANCOVA) was utilized in order to test whether there were differences in the equation's parameters between males and females, using sex as a covariant. A t-test was used to verify whether the equation's slope was different from $1\left(\mathrm{H}_{0}: \mathrm{b}=1\right)$. The Spearman's correlation test was used to verify the existence of any correlation between temperature variation and abundance of ovigerous females throughout the year. The level of confidence for rejecting the null hypothesis was considered to be below $5 \%$. All data was tested for normality and homogeneity of variance prior to any test by means of the Shapiro-Wilk test and Levene's test, respectively. We used Prism version 8.0.1 (GraphPad, CA, USA) and R version 3.6.3 (R Core Team, 2020) for graphing and analysis.

\section{RESULTS}

Abiotic factors: Temperatures in the river varied throughout the year (Table 1). The highest temperature registered was $27.6^{\circ} \mathrm{C}$ in December, while the lowest value $\left(25.3{ }^{\circ} \mathrm{C}\right)$ was registered in June. 
TABLE 1

Means of temperature readings by month in 2009

\begin{tabular}{cc} 
Month & Temperature $\left({ }^{\circ} \mathrm{C}\right)$ \\
Jan & 27.1 \\
Feb & 26.7 \\
Mar & 26.8 \\
Apr & 27 \\
May & 26.4 \\
Jun & 25.3 \\
Jul & 25.5 \\
Aug & 25.8 \\
Set & 26.4 \\
Oct & 26.9 \\
Nov & 27.5 \\
Dec & 27.6 \\
\hline
\end{tabular}

Population structure: In total, 517 individuals were collected, representing 328 males and 186 females (169 ovigerous females). The smallest female was ovigerous, allowing us to assume that all the individuals sampled were fully developed (Table 2). There was a significant deviation from the 1:1 normal sex ratio towards more males in all but three months (Table 3).

The males were dominant in the size classes 25 - 29.9, 30 - 34.9 and 35 - $39.9 \mathrm{~mm}$, while females showed highest frequency in the $20-24.9 \mathrm{~mm}$ size class (Fig. 2). Patterns were unimodal for females and polymodal for males. The non-parametric Mann-Whitney U test demonstrated that there are differences between the sexes in TL $(\mathrm{P}<0.001)$ (Fig. 3).

The allometry relationships (Fig. 4) demonstrated to be negative $(\mathrm{b}<1)$ in males and females (t-test, $\mathrm{P}<0.05$ ), which means that the carapace length increases in a higher rate than the carapace width. The ANCOVA analysis demonstrated that the slope (b) and intercept (a) were significantly different among males and females $(\mathrm{P}<0.01)$, denoting that the patterns of growth are different.

TABLE 2

Minimum, maximum, mean and standard deviation (SD) of the carapace length (CL) and total length (TL) for males and females

\begin{tabular}{lccccccccc}
\multicolumn{1}{r}{ Sex } & \multicolumn{4}{c}{ TL $(\mathrm{mm})$} & \multicolumn{4}{c}{ CL $(\mathrm{mm})$} \\
& Min. & Max. & Mean & SD & Min. & Max. & Mean & SD \\
Males & 37.45 & 96.60 & 73.04 & 10.829 & 13.60 & 47.50 & 31.43 & 5.222 \\
Fem. & 38.00 & 87.40 & 57.65 & 8.648 & 13.00 & 39.20 & 22.69 & 3.804 \\
\hline
\end{tabular}

TABLE 3

Number of males and females in each month and sex ratio (males: females)

\begin{tabular}{|c|c|c|c|c|}
\hline Month & Number of males & Number of females & Sexual proportion & $\chi^{2}$ test \\
\hline Jan & 30 & 13 & $2.5: 1$ & $\mathrm{P}<0.05$ \\
\hline Feb & 30 & 10 & $3: 1$ & $\mathrm{P}<0.05$ \\
\hline Mar & 28 & 12 & $2.33: 1$ & $\mathrm{P}<0.05$ \\
\hline Apr & 31 & 18 & $1.72: 1$ & $\mathrm{P}<0.05$ \\
\hline May & 25 & 17 & $1.47: 1$ & $\mathrm{P}<0.05$ \\
\hline Jun & 24 & 21 & $1.14: 1$ & NS \\
\hline Jul & 23 & 20 & $1.15: 1$ & NS \\
\hline Aug & 24 & 15 & $1.14: 1$ & NS \\
\hline Sep & 30 & 16 & $1.87: 1$ & $\mathrm{P}<0.05$ \\
\hline Oct & 30 & 16 & $1.87: 1$ & $\mathrm{P}<0.05$ \\
\hline Nov & 25 & 13 & $1.92: 1$ & $\mathrm{P}<0.05$ \\
\hline Dec & 28 & 15 & $1.86: 1$ & $\mathrm{P}<0.05$ \\
\hline Total & 329 & 186 & $1.76: 1$ & $\mathrm{P}<0.05$ \\
\hline
\end{tabular}

NS $=$ Non-significant. 

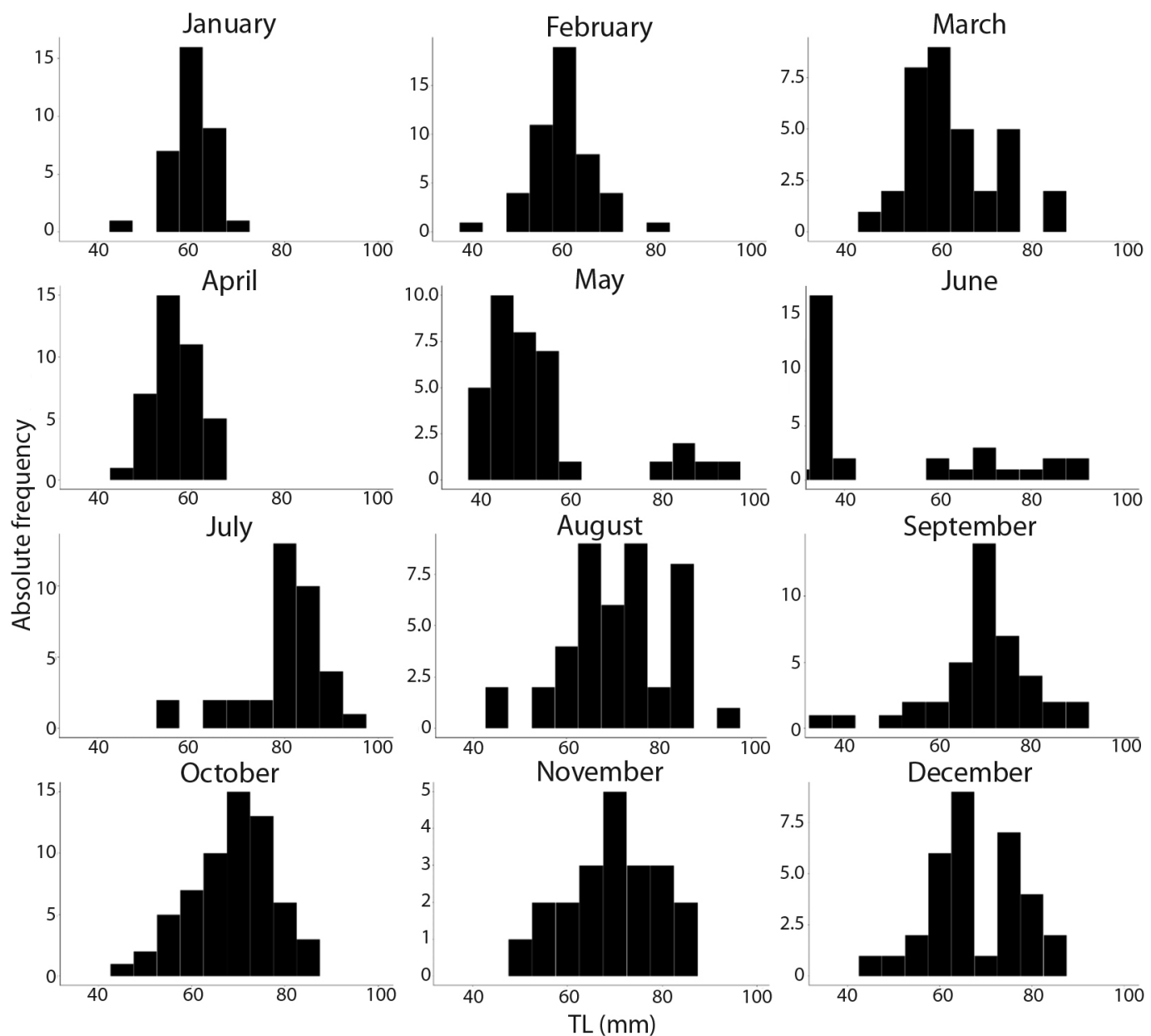

Fig. 6. Frequency of size classes $(5 \mathrm{~mm})$ of total length for each month.

entire year, characterizing the reproduction as continuous. The breeding period in the Atyidae family demonstrated to be continuous in many studies (Benzie \& De Silva, 1988; De Silva, 1990; Idrisi \& Salman, 2005; Leuven, Van Der Brink, \& Van Der Velde, 2008). It is possible that the rainy season is able to influence peaks (Hoarau, 2018; Hoffman \& Negreiros-Fransozo, 2010). Galvão and Bueno (2000) found out higher abundance of ovigerous females of $A$. scabra in the months that registrated the higher temperatures, while Lopes, Frédou, Silva, Calazans and Peixoto (2017) reported positive correlation between the percentage of mature females and temperature in the species Xiphopenaeus kroyeri Heller 1862, suggesting that this abiotic factor does influence reproductive peaks in caridean prawns. In this study, a different pattern was observed, which consisted in a higher abundance of ovigerous females in the months with lower temperatures. A correlation with the rainfall is possible, probably caused by the increase in the amount of nutrients in the rainy season. Similar patterns of reproductive period were also observed in other caridean shrimps (Mossolin \& Bueno, 2002; Terossi \& Mantelatto, 2010), suggesting that these patterns are common for this group of crustaceans. The fact that the smallest female $(13.00 \mathrm{~mm}$ of carapace length) was ovigerous is an indicative that much probably the juveniles in this specific population are below this size. 
The different patterns of relative growth observed among the sexes emphasizes that the males, during development, invest energy in the development of structure related to sexual behavior, while females invest their energy in developing its gonads, explaining the fact of females being predominant in lower size classes (Correa \& Thiel, 2003a). It is a concern that caridean shrimps show sexual guarding behavior, which consists in the male "protecting" the female with the chelipeds (Gualberto, Almeida \& Menin, 2012). It is clear that this pattern is shown by the studied species. Lorán-Núñez et al. (2009) also found higher size and abundance in males of two rivers in México, a pattern also shown by the population analyzed in this study.

The sex ratio favorable to males almost the entire year can be explained as a result of different configurations of migration and mortality between the sexes, which can be explained as relations between age at sexual maturity and its relationship with the life expectancy (Rondeau \& Saint-Marie, 2001; Siegel, Damm, $\&$ Neudecker, 2008). Sex ratio can also be an important factor when it comes to determining parameters of sexual selection, like direction and intensity (Correa \& Thiel, 2003b). This result was also found for Atya scabra by other authors (Galvão \& Bueno, 2000; Lorán-Núñes et al., 2009; Almeida et al., 2010).

The data exposed in this article is essential to expand the knowledge about the freshwater crustaceans that live alongside rivers in Northeast Brazil, contributing to draw sustainable fishery managing strategies by the local government, in order to ensure that the population continues to be stable. The correlation between variation of temperature and the abundance of ovigerous females was clear. Although, it is possible that variation in rainfall may also affect the frequency of ovigerous females, caused by an increase in nutrient availability. We suggest that restrictions in the months of May and June must be implemented. This is based on the observations that recruitment reaches its peaks in these periods. These measures can be valuable when it comes to conservation of the fishing stock. The sexual dimorphism present in the species was reinforced by our data, being highly similar to other studies with the animal. The male-biased sex ratio can possibly indicate clues for sexual selection occurring in the species and is a common pattern in Atyid prawns, something that deserves investigation.

Ethical statement: authors declare that they all agree with this publication and made significant contributions; that there is no conflict of interest of any kind; and that we followed all pertinent ethical and legal procedures and requirements. All financial sources are fully and clearly stated in the acknowledgements section. A signed document has been filed in the journal archives.

\section{RESUMEN}

Biología poblacional y dimorfismo sexual en la gamba de agua dulce Atya scabra (Decapoda: Atyidae) en el río Contas, Bahía, Brasil. Introducción: Los crustáceos tienen importancia económica y ecológica y el papel de los crustáceos carideanos en los entornos lénticos es crucial para mantener la estructura trófica. La especie Atya scabra se asocia ocasionalmente con la pesca, especialmente en el noreste y norte de Brasil. Objetivo: Determinar la estructura de la población, período reproductivo, patrones de crecimiento y la distribución de las clases de tamaño entre los sexos en una población de gambas $A$. scabra en el río de Contas, Bahía, Brasil. Métodos: Se tomaron muestras de los individuos en un período de un año pasando tamices en la vegetación marginal y usando redes de arrastre (dragnets). En el laboratorio, registramos el sexo de los individuos y los medimos utilizando un paquímetro con precisión de $0.001 \mathrm{~mm}$. Las dimensiones medidas fueron CL (longitud del caparazón), TL (longitud total) y CW (ancho del caparazón). Para analizar los datos, se construyeron modelos lineales para las relaciones CL $\times$ CW y se determinó el tipo de alometría para cada sexo. Los individuos se agruparon en clases de tamaño de intervalos de $5 \mathrm{~mm}$. La prueba de chi-cuadrado $\left(\chi^{2}\right)$ se utilizó para determinar desviaciones en la proporción de sexos 1:1. La proporción de hembras ovígeras se registró en cada mes para determinar el período de reproducción. Resultados: Se recolectaron un total de 517 individuos, 328 machos y 186 hembras, de las cuales 169 eran ovígeras. Los machos mostraron una distribución polimodal en las clases de tamaño y fueron significativamente más grandes que las hembras, las cuales presentaron una distribución unimodal en las clases de tamaño. Los patrones de crecimiento observados demostraron que ambos sexos presentan alometría negativa. Sin embargo, se detectó dimorfismo sexual al comparar los parámetros de crecimiento. Se 
tomaron muestras de hembras ovígeras durante todo el año y los datos de frecuencia de tamaño demostraron que el reclutamiento también se produce durante todo el año, lo que nos permitió clasificar la reproducción como continua. Conclusiones: Nuestros datos son esenciales para elaborar estrategias sostenibles de gestión pesquera. Sugerimos un tamaño mínimo de captura de $70 \mathrm{~mm}$ y restricciones de captura desde mayo hasta agosto.

Palabras clave: ecología; agua dulce; limnología; conservación; morfometría.

\section{REFERENCES}

Almeida, A.O., Coelho, P.A., Luz, J.R., Santos, J.T.A., \& Ferraz, N.R. (2008). Decapod crustaceans in fresh waters of southeastern Bahia, Brazil. Revista de Biología Tropical, 56, 1225-1254.

Almeida, A.O., Mossolin, E.C., \& Luz, J.R. (2010). Reproductive biology of the freshwater shrimp Atya scabra (Leach, 1815) (Crustacea: Atyidae) in Ilhéus, Bahia, Brazil. Zoological Studies, 49(2), 243-252.

Amaral, A.C.Z. (2005). Invertebrados aquáticos. In A.B.M. Machado, C.S. Martins, \& G.M. Drummond (Eds.), Lista da fauna Brasileira ameaçada de extinção: incluindo espécies quase ameaçadas e deficientes em dados (pp. 99-118). Minas Gerais, Brazil: Fundação Biodiversitas.

Benzie, J.A., \& De Silva, P.K. (1988). The distribution and ecology of the freshwater prawn Caridina singhalensis (Decapoda, Atyidae) endemic to Sri Lanka. Journal of Tropical Ecology, 4(4), 347-359.

Correa, C., \& Thiel, M. (2003a). Mating systems in caridean shrimp (Decapoda: Caridea) and their evolutionary consequences for sexual dimorphism and reproductive biology. Revista Chilena de Historia Natural, 76(2), 187-203.

Correa, C., \& Thiel, M. (2003b). Population structure and operational sex ratio in the rock shrimp Rhynchocinetes typus (Decapoda: Caridea). Journal of Crustacean Biology, 23(4), 849-861.

Costa, T., \& Soares-Gomes, A. (2008). Relative growth of the fiddler crab Uca rapax (Smith) (Crustacea: Decapoda: Ocypodidae) in a tropical lagoon (Itaipu), Southeast Brazil. Pan-American Journal of Aquatic Sciences, 3(2), 94-100.

Covich, A.P. (1988). Atyid shrimp in the headwaters of the Luquillo Mountains, Puerto Rico: Filter feeding in natural and artificial streams. Internationale Vereinigung für theoretische und angewandte Limnologie: Verhandlungen, 23(4), 2108-2113.
Debrot, A.O. (2003). The freshwater shrimps of Curaçao, West Indies (Decapoda, Caridea). Crustaceana, 76(1), 65-76.

De Grave, S., Cai, Y., \& Anker, A. (2008). Global diversity of shrimps (Crustacea: Decapoda: Caridea) in freshwater. Hydrobiologia, 55, 287-293.

De Grave, S., \& Fransen, C.H. (2011). Carideorum catalogus: the recent species of the dendrobranchiate, stenopodidean, procarididean and caridean shrimps (Crustacea: Decapoda). Zoologische Mededelingen, $85,195-589$.

De Silva, K.H.G.M. (1990). Caridina kumariae, a new species from Sri Lanka and some aspects of its ecology (Decapoda, Atyidae). Crustaceana, 59, 9-24.

Galvão, R., \& Bueno, S.L. (2000). Population structure and reproductive biology of the camacuto shrimp, Atya scabra (Decapoda, Caridea, Atyidae), from São Sebastião, Brazil. Crustacean Issues, 12, 291-300.

Girard, V., Monti, D., Valade, P., Lamouroux, N., Mallet, J.P., \& Grondin, H. (2014). Hydraulic preferences of shrimps and fishes in tropical insular rivers. River Research and Applications, 30(6), 766-779.

Gualberto, T.L., Almeida, L.O., \& Menin, M. (2012). Population structure, fecundity and ecological aspects of freshwater shrimp species (Decapoda, Palaemonidae) of an urban forest fragment in central Amazonia, Brazil. Crustaceana, 85(10), 1205-1219.

Hartnoll, R.G. (1974). Variation in growth pattern between some secondary sexual characters in crabs (Decapoda Brachyura). Crustaceana, 27, 131-136.

Herrera-Correal, J., Mossolin, E.C., Wehrtmann, I.S., \& Mantelatto, F.L. (2013). Reproductive aspects of the caridean shrimp Atya scabra (Leach, 1815) (Decapoda: Atyidae) in São Sebastião Island, southwestern Atlantic, Brazil. Latin American Journal of Aquatic Research, 41(4), 676-684.

Hoarau, P. (2018). Size at maturity, reproduction and recruitment in an amphidromous shrimp Caridina serratirostris De Man, 1892 in Reunion Island (Decapoda: Atyidae). Cahiers scientifiques de l'océan Indien occidental, 9, 1-10.

Hobbs, H.H., \& Hart, J.R. (1982). The shrimp genus Atya (Decapoda: Atyidae). Washington, USA: Smithsonian Institution Press.

Hoffmann, P., \& Negreiros-Fransozo, M.L. (2010). Reproductive cycle and fecundity of Potimirim glabra (Kingsley, 1954) (Caridea, Atyidae) from a littoral stream. Invertebrate Reproduction \& Development, 54(3), 133-141.

Idrisi, N., \& Salman, S.D. (2005). Distribution, development, and metabolism of larval stages of the warmwater shrimp, Caridina babaulti basrensis 
(Decapoda, Atyidae). Marine and Freshwater Behaviour and Physiology, 38(1), 31-42.

Leuven, R.S.E.W., Van Den Brink, F.W.B., \& Van Der Velde, G. (2008). Biometrics and fecundity of the freshwater shrimp, Caridina nilotica (P. Roux, 1833) (Decapoda, Caridea, Atyidae) in the lower Nile River (Egypt). Crustaceana, 81, 227-239.

Lopes, D., Frédou, F.L., Silva, E., Calazans, N., \& Peixoto, S. (2017). Reproductive cycle of seabob shrimp Xiphopenaeus kroyeri (Crustacea, Penaeidea) from the northeast coast of Brazil. Invertebrate Reproduction \& Development, 61(3), 137-141.

Lorán-Núñez, R.M., Valdéz-Guzmán, A.J., \& MartínezIsunza, F.R. (2009). Estudio biológico-pesquero del "burro" Atya scabra en el río de los Pescados y río Actopan, Veracruz, México. Ciencia Pesquera, 17(1), 5-16.

Martínez-Mayén, M., Román-Contreras, R., RochaRamírez, A., \& Chazaro-Olvera, S. (2000). Relative growth of Atya margaritacea A. Milne-Edwards, 1864 (Decapoda, Atyidae) from the southern Pacific coast of Mexico. Crustaceana, 73(5), 525-534.

Melo, G.A.S. (2003). Famílias Atyidae, Palaemonidae e Sergestidae. In G.A.S. Melo (Ed.), Manual de Identificação dos Crustacea Decapoda de Água Doce do Brasil (pp. 289-415). São Paulo, Brazil: Edições Loyola.

Mossolin, E.C., \& Bueno, S.L. (2002). Reproductive biology of Macrobrachium olfersi (Decapoda, Palaemonidae) in São Sebastião, Brazil. Journal of Crustacean Biology, 22(2), 367-376.
Siegel, V., Damm, U., \& Neudecker, T. (2008). Sex-ratio, seasonality and long-term variation in maturation and spawning of the brown shrimp Crangon crangon (L.) in the German Bight (North Sea). Helgoland Marine Research, 62(4), 339.

R Core Team. (2020). R: A language and environment for statistical computing (Version 3.6.3). R Foundation for Statistical Computing, Vienna, Austria. Retrieved from https://www.r-project.org

Rahman, M.M., \& Ohtomi, J. (2018). Relative growth and morphological sexual maturity of the deep-water velvet shrimp Metapenaeopsis sibogae (Crustacea, Decapoda, Penaeidae). Invertebrate Reproduction \& Development, 62(3), 125-132.

Rondeau, A., \& Sainte-Marie, B. (2001). Variable mateguarding time and sperm allocation by male snow crabs (Chionoecetes opilio) in response to sexual competition, and their impact on the mating success of females. The Biological Bulletin, 201(2), 204-217.

Terossi, M., \& Mantelatto, F.L. (2010). Sexual ratio, reproductive period and seasonal variation of the gonochoric shrimp Hippolyte obliquimanus (Caridea: Hippolytidae). Marine Biology Research, 6(2), 213-219.

Torati, L.S., Page, T., De Grave, S., \& Anker, A. (2011). Atyidae and Palaemonidae (Crustacea: Decapoda: Caridea) of Bocas del Toro, Panama. Check List, 7, 798.

Verdi, A.C. (1995). La estructura ovárica de Macrobrachium borellii (Nobili, 1896) (Crustacea, Caridea, Palaemonidae). Revista Brasileira de Biologia, 55, 193-199. 